Institute of $\mathbf{F}_{\text {ood and }} \mathbf{A}_{\text {gricultural }} \mathbf{S}_{\text {ciences }}$

\title{
Multi-Cavity Collection: A Method for Sampling Bulk Solutions from Plug Media 1
}

Chen, J., Y. Huang, C. A. Robinson, and R. D. Caldwell ${ }^{2}$

Plug production, a term that was not a part of the floriculture vocabulary twenty years ago, now has become significant to the floriculture industry. Seeds are sown, and tissue cultured explants or cuttings are implanted in medium-filled, multi-cavity cells of plastic trays. After a few weeks, roots become adhered with medium. Seedlings, liners or cuttings pulled from cells are called plugs. In other words, plugs are containerized transplants with self-enclosed root systems.

Pluses and minuses in plug production. The advantages of growing seedlings, explants, or cuttings from plugs include minimized time and labor for transplanting, reduced root loss, decreased disease spread, more uniform growth, faster crop time, increased production, and easy mechanization.

The main disadvantage is that plugs may be more challenging to inexperienced growers. A tray generally has a size of 21 ” x 11 " x 2.5 " (length $\mathrm{x}$ width $\mathrm{x}$ depth) but varies greatly in cell number ranging from 50 to 800 cells per tray. The very small volume of medium in each plug is vulnerable to water stress and is also subject to rapid changes in $\mathrm{pH}$ and nutrient content. Recent studies have shown that $80 \%$ of nutritional problems are due to fluctuation in medium pH and soluble salts levels (Styer, 1996). Therefore, weekly monitoring of medium $\mathrm{pH}$ and soluble salts levels has been recommended (Fonteno et al., 1995).

Bulk solution extraction methods. The most popular and convenient way of monitoring medium $\mathrm{pH}$ and soluble salts is to analyze bulk or root-zone solutions. There are four common methods available for extracting bulk solutions from container media (Huang et al., 2000). Briefly, (1) 1:2 dilution and (2) 1:5 dilution by volume require that one part air-dried medium be mixed with two or five parts of distilled or deionized water; the mix is stirred and allowed to equilibrate for 30 minutes, then filtered using filter paper or several folds of cheese cloth; (3) pour-through (PT) method needs an adequate amount of distilled or deionized water to be slowly poured over the surface of near-saturated container-medium so that about $50 \mathrm{~mL}$ of bulk solution can be collected in a beaker as leachate from drainage holes; (4) saturated media extract (SME) requires about $500 \mathrm{cc}$ of medium sampled from pots; the sampled medium then is mixed with distilled or deionized water until just saturated (medium surface glistens); after

1. This document is ENH855, a series of the Environmental Horticulture Department, Florida Cooperative Extension Service, Institute of Food and Agricultural Science, University of Florida. First published: December 2001. Please visit the EDIS website at http://edis.ifas.ufl.edu.

2. Jianjun Chen, Assistant Professor, Plant Physiologist, Yangfeng Huang, Visiting Scholar, and Cynthia A. Robinson, former Biological Scientist, and Russell D. Caldwell, Biological Scientist at the University of Florida, Institute of Food and Agricultural Sciences, Environmental Horticultural Department and Mid-Florida Research and Education Center, Apopka, FL 32703.

The Institute of Food and Agricultural Sciences is an equal opportunity/affirmative action employer authorized to provide research, educational information and other services only to individuals and institutions that function without regard to race, color, sex, age, handicap, or national origin. For information on obtaining other extension publications, contact your county Cooperative Extension Service office. Florida Cooperative Extension Service/Institute of Food and Agricultural Sciences/University of Florida/Christine Taylor Waddill, Dean. 
equilibrating for $1.5 \mathrm{~h}$, solutions are extracted using a vacuum filter.

Obviously, these methods are not suitable for extracting bulk solutions from plugs because the limited volume of plug/cell media is not suitable for typical saturated media extract (SME), 1:2, or 1:5 sampling. Additionally, the multi-cavity unit designs are not favorable for the standard water pour-through method. Recently, a press extraction method (PEM, pressing the top of the plug to expel solution) was developed (Scoggins et al., 2000). However, the method is invasive, because the necessary pressing can cause irreparable damage to the plants, and, also, medium or lime particles may be forced into solution that may affect soluble salts readings.

\section{The multi-cavity collection method (MCC).} Here, we introduce a modified pour-through method, multi-cavity collection (MCC), which was developed for root-zone solution extractions from plugs without plant damage (Huang et al., 2001). The MCC includes four steps: (1) select plug trays of interest one hour after fertigation; (2) place a clean, accommodating, non-permeable plate beneath the multi-cavity unit; (3) collect root-zone solution (about $50 \mathrm{~mL}$ ) by slowly and evenly pouring distilled or deionized water onto the surfaces of the individual/joined cavities; and (4) pour the leachate into a suitable container for analyses of $\mathrm{pH}, \mathrm{EC}$, or nutrients. It is important to have replications, i.e. extract solutions from at least three trays of the same treatment. Measure the solution separately but obtain a mean by averaging the readings. Additionally, if the water used is not deionized water, readings of electrical conductivity of the water should be taken and must be subtracted from the readings of root-zone solutions.

\section{Formula for converting soluble salts readings} from one to another. Soluble salts and $\mathrm{pH}$ of bulk solutions extracted from different plug media using the MCC, PEM, SME, and 1:2 methods were compared (Huang et al., 2001). Results showed that there were no significant differences in $\mathrm{pH}$ readings regardless of extraction methods. Soluble salts readings varied significantly according to extraction methods but were well paralleled. Simple correlation analyses proved that high correlation existed among the four methods. Therefore, regression analyses were performed to provide formulas for converting soluble salts readings from one method to another (Table 1).

Table 1. Formulas for converting soluble salts readings from one extraction method to another in plug production.

\begin{tabular}{|c|c|c|c|}
\hline $\begin{array}{l}\text { To convert } \\
\text { reading } \\
\text { of }(x)\end{array}$ & $\begin{array}{l}\text { Multiply } \\
\text { (x) by }\end{array}$ & Add & To obtain \\
\hline MCC & 0.89 & 0.07 & PEM \\
\hline MCC & 0.49 & 0.14 & SME \\
\hline MCC & 0.39 & 0.03 & $1: 2$ \\
\hline PEM & 0.96 & 0.07 & MCC \\
\hline PEM & 0.56 & 0.09 & SME \\
\hline PEM & 0.49 & 0.04 & $1: 2$ \\
\hline SME & 1.36 & 0.10 & MCC \\
\hline SME & 1.45 & 0.02 & PEM \\
\hline SME & 0.85 & 0.10 & $1: 2$ \\
\hline $1: 2$ & 1.25 & 0.39 & MCC \\
\hline $1: 2$ & 1.45 & 0.28 & PEM \\
\hline $1: 2$ & 0.97 & 0.19 & SME \\
\hline \multicolumn{4}{|c|}{$\begin{array}{l}\text { Suppose a soluble salts reading of } 1.0 \mathrm{dS} / \mathrm{m} \text { is obtained } \\
\text { using the MCC method. To convert this reading to the } \\
\text { equivalent PEM, SME, and } 1: 2 \text { readings, use the above } \\
\text { table as follows: } \\
1.0 \times 0.89+0.07=0.96 \mathrm{dS} / \mathrm{m} \text { (PEM) } \\
1.0 \times 0.49+0.14=0.63 \mathrm{dS} / \mathrm{m}(\mathrm{SME}) \\
1.0 \times 0.39+0.03=0.42 \mathrm{dS} / \mathrm{m}(1: 2) \\
\text { Therefore, if the PEM, SME, and } 1: 2 \text { methods are used } \\
\text { to extract root-zone solution of this plug medium, the } \\
\text { soluble salts readings should be } 0.96,0.63 \text {, and } 0.42 \\
\mathrm{dS} / \mathrm{m} \text { respectively. }\end{array}$} \\
\hline
\end{tabular}

The advantages of the MCC method. The MCC is a method modified from the standard pour-through (PT). The differences between the MCC and PT lie in the facts that (1) the former is developed for plug media, while the latter has been used for container media, and (2) leachate collection using the MCC requires a plate that can accommodate the plug tray, but leachate collection by the PT needs beakers or other similar containers that hold pots.

The MCC method, like the PEM, does not require medium removal from plugs or the waiting typically needed for medium-water equilibrium. The 
MCC offers reliable results and can be performed right on the greenhouse bench without special equipment. The MCC has advantages over the PEM as the MCC is non-destructive to plants, and root-zone solutions collected by the MCC have less media and/or lime particles than those collected by the PEM. MCC provides an alternative method for readily extracting plug root-zone solutions for monitoring soluble salts, $\mathrm{pH}$, and nutrient levels.

\section{Literature Cited}

Fonteno, W. C., D. A. Bailey, and P. V. Nelson. 1995. Squeeze your plugs for simple, accurate nutrient monitoring. GrowerTalks 59 (9):22-27.

Huang, Y., J. Chen, R. D. Caldwell, and C. A. Robinson. 2001. Introducing a multi-cavity collection method for extraction plug root-zone solutions Proc. Fla. State Hort. Soc. 134:243-245.

Huang, Y., J. Chen, L. Qu, R. D. Caldwell, and C. A. Robinson. 2000. Interpretation of soluble salts and $\mathrm{pH}$ of bulk solutions extracted by different methods. Proc. Fla. State Hort. Soc. 133:154-157.

Scoggins, H. L., D. A. Bailey, and P. V. Nelson. 2000. Bench press for plug fitness. Ornamental Outlook. 9 (12):30, 32, 34, and 35.

Syter, R. C. 1996. Key factors of water media and nutrition. GrowerTalks 60 (9): 22-30. 